\title{
PERMIT REQUIREMENTS FOR DEVELOPMENT OF ENERGY AND OTHER SELECTED NATURAL RESOURCES FOR THE \\ STATE OF WEST VIRGINIA
}

PREPARED FOR

APPALACHIAN REGIONAL COMMISSION

AND THE

U.S. GEOLOGICAL SURVEY

BY BARRY LAWSON ASSOCIATES

This material is the result of tax-supported research and as such it is not subject to copyright. It may be freely reprinted with customary credit to the source. None of the findings, conclusions, or recommendations in the data are endorsed by the Appalachian Regional Commission, or the U.S. Geological Survey. 


\section{ACKNOWLEDGEMENTS}

The West Virginia Permit Guide was prepared under the direction of the U.S. Geological Survey (USGS) in cooperation with the Appalachian Regional Commission and the State of West Virginia. Funding support for this project was provided by the USGS Environmental Affairs office (EAO). Wilbert J. Ulman and James Frederick of the USGS Resource Planning and Analysis Office (RPAO) served respectively as Program Manager and Project Coordinator during the preparation of this guidebook. Both the RPAO and EAO are under the Office of Earth Sciences Applications. John Demchalk, Energy and Reclamation Advisor of the Appalachian Regional Commission, acted as Project Manager. Barry Lawson Associates, Inc. (BLA), of Boston, Massachusetts, was responsible for compiling all available information and producing the final document. Barry Lawson acted as Principal Investigator and Barbara Turoff as Project Coordinator during the preparation of this guidebook at BLA.

Request for information concerning this publication should be directed to the following locations:

$\begin{array}{ll}\text { Governor's Office of Economic } & \text { Appalachian Regional Commission } \\ \text { and Community Development } & 1666 \text { Connecticut Avenue, N.W. } \\ 1900 \text { Washington Street, East } & \text { Washington, D.C. 20235 } \\ \text { Charleston, West Virginia 25305 } & \end{array}$

or

U.S. Geological Survey

Environmental Affairs Office

760 National Center

Reston, Virginia 22092

\section{PUBLICATION AVAILABILITY}

This West Virginia Permit Guide is available as an Open-File Report \#81-1285 from:

U.S. Geological Survey

Open-File Services Section

Branch of Distribution

Box 25425

Denver Federal Center

Denver, Colorado $\mathbf{8 0 2 2 5}$ 
STATE PERMIT REQUIREMENTS FOR DEVELOPMENT OF ENERGY AND OTHER SELECTED NATURAL RESOURCES

STATE PERMIT GUIDES WILI BE AVAILABLE BY JANUARY 1982 FROM, USGS OPEN-FILE SERVICES SECTION, BRANCH OF DISTRIBUTION, BOX 25425, DENVER, COLORADO 80225

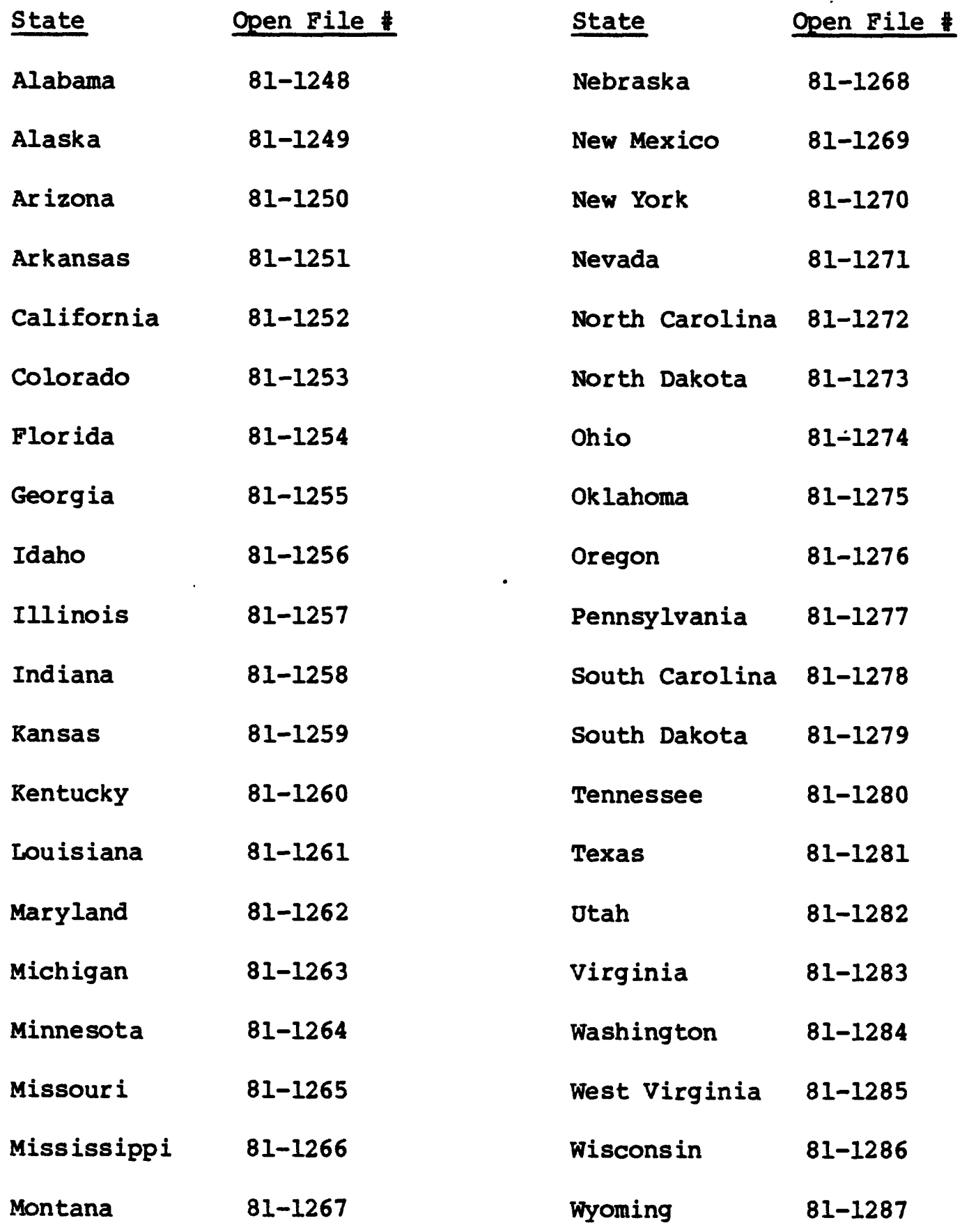




\section{CONTENTS}

Page

Section 1.0 Introduction...................... 1

Section 2.0 State Policy and Procedures

for Consolidated Permit Program

Chapter $2.1 \quad$ State Clearinghouse............. 4

2.2 Consolidated Permit Program....... 5

Section 3.0 Resource Extraction

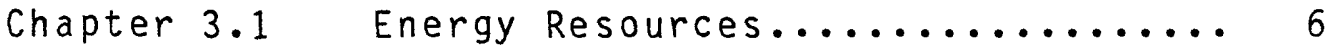

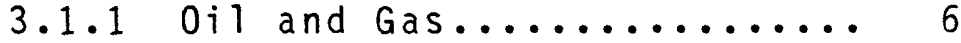

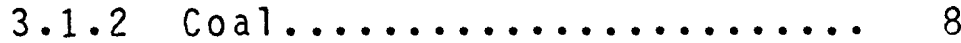

3.2 Minerals Mining............... 13

Section 4.0 Land Use Regulation

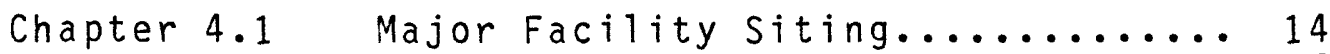

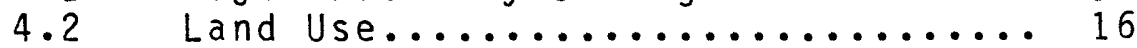

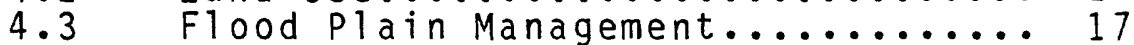

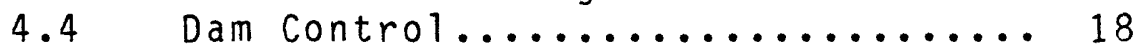

Section 5.0 Environmental Quality Management

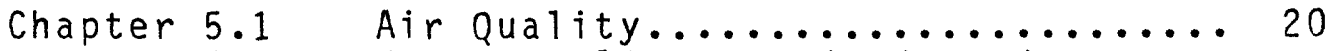

5.2 Water Quality Standards and

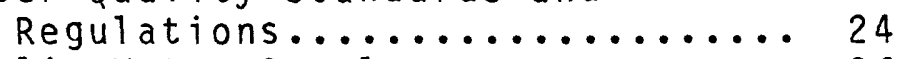

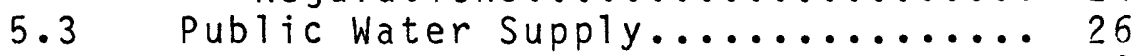

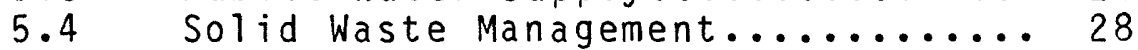

5.5 Hazardous Waste Management........ 30

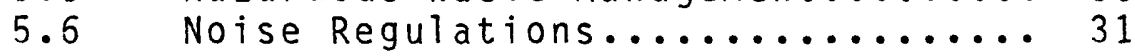

Section 6.0 Social/Ecological Preservation

Chapter 5.1 Rare and Endangered Species....... 32

6.2 Archaeological and Historical..... 34

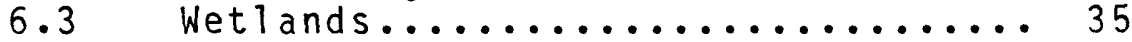

Section 7.0 Local Regulatory Policy

Chapter 7.1 Local Government Land Use and Natural Resource

Control Enabling Laws......... 36 
SECTION 1.0

INTRODUCTION 
This state permit guide for West Virginia is one in a series of guidebooks prepared to explain state regulations governing the environmental consequences of the development of energy and other natural resources on State and private land. (This guidebook does not address Federal permits required on Federal lands within the State.) It is designed to provide individuals in both government and the private sector with a concise compilation of State regulations and policies dealing primarily with permitting processes concerning natural resource management and development.

The increasing number of state policies and regulations concerning natural resources, especially energy resources, makes it difficult to gain an accurate yet workable understanding of State procedures without considerable research and technical assistance. The permit guide therefore serves as a reference document to those seeking state environmental and energy resource permit information. It is intended to show clearly what is required by regulatory and permit-issuing state agencies relative to a number of resource- and energy-related areas.

All the information in this permit guide was obtained through personal interviews with representatives of the state agencies in West Virginia responsible for the management of a particular resource area. Additional information was obtained directiy from the appropriate state laws and regulations. It should be noted that the research was done during the spring of 1981 and that regulations are subject to change.

Most of the state agencies responsible for issuing permits require that applications be submitted on standard forms they provide. Such forms are usually numbered and named by the agency. If no form number is identified in the text, the application form should be requested by name.

The permit guide does not include a legal analysis or interpretation of statutes or regulations, nor is it intended to serve legal purposes. It provides a general summary of environmental and energy resource permit processes within a number of state agencies, and supplies information on selected state and local 
policies and procedures, land use regulations, and environmental management. For each subject, the permit guide provides the following information:

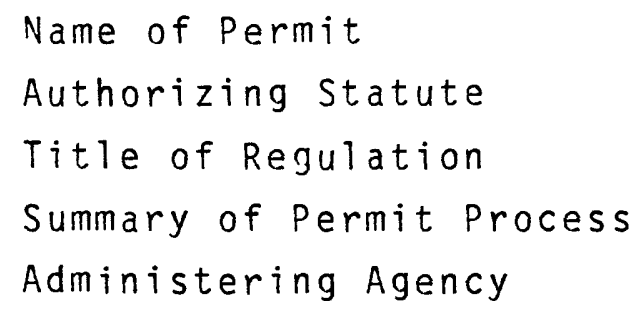

Corresponding to the growth of Federal, State, and local regulatory powers, the number of formal approvals necessary to initiate a specific development activity has increased substantially. Although each chapter of this guide outlines the major State approvals required for a particular development activity, they do not provide a comprehensive list of the broad range of permits, licenses, and approvals which could potentially be required for an activity, nor do they cross reference other potentially relevant chapters of the guide.

To demonstrate the complexity of this situation, the introduction to the Coal Mining chapter (Chapter 3.1.2) of this guide includes a list of all state approvals which could potentially be required to initiate coal mining activities depending on the nature, location, and magnitude of the proposed activities. Such detailed cross referencing and analysis for all chapters is beyond the purpose and scope of this document. Therefore, initial direct contact with the appropriate state agency(ies) is recommended for anyone contemplating a project requiring a permit or other state agency approval. 
The following agencies were surveyed and have verified the content of the elements of their particular resource areas:

State clearinghouse office

Governor's Office of Economic and Community Development

Department of Mines

Office of $0 i 1$ and Gas

Department of Natural Resources

Division of Reclamation

Division of Water Resources

Division of Wildlife Resources

Division of Environmental Analysis

Public Service Commission

West Virginia Air Pollution Control Commission

Department of Health

Office of Environmental Health Services Water Supply Division

Solid Waste Division

Department of Culture and History

Historic Preservation Unit 
SECTION 2.0

STATE POLICY AND PROCEDURES FOR CONSOLIDATED PERMIT PROGRAM 
INTRODUCTION: The West virginia state clearinghouse is responsible for the implementation and coordination of provisions as set forth in the U.S. Office of Management and Budget revised Circular A-95. Through the State Clearinghouse, applicants for Federal assistance are given the opportunity to receive input from interested parties and state agencies on their proposal. The State clearinghouse is designed to identify any duplication in programs and assure the proposal's consistency with state plans, goals, and objectives. The State clearinghouse coordinates activities which allow the Governor and his representatives to stay informed of the purpose and amount of grants awarded to units of state or local government.

Applications for Federal assistance must be submitted to the State Clearinghouse officer, who distributes the applications to the appropriate state agencies for review and comment. Agency comments are then compiled and forwarded to the Federal agency from which funding is requested. The State clearinghouse acts to resolve disputes between the applicant and commenting agencies, and among commenting agencies. The State clearinghouse may also issue its own comments on an application.

ADMINISTERING AGENCY:

State A-95 Clearinghouse office

Building 6 , Room 548

State Capitol

Charleston, WV 25305

(304) $348-4010$ 


\section{CONSOLIDATED PERMIT PROGRAM}

INTRODUCTION: The State of West Virginia does not have a one-stop permit agency at present. There also is no State equivalent of the National Environmental Policy Act. However, the Governor's Office of Economic and Community Development (GOECD) assists industries in dealing with State and Federal agencies having regulatory responsibilities. The GOECD has also entered into a cooperative agreement with the U.S. Environmental Protection Agency which calls for joint exploration of the potential for consolidating certain environmental permits.

ADMINISTERING AGENCY: Governor's Office of Economic and Community Development 1900 Washington Street, East Charleston, WV 25305 (304) 348-0400 
SECTION 3.0

RESOURCE EXTRACTION

$5 a$ 
CHAPTER 3.1

ENERGY RESOURCES

\section{1 .1 OIL AND GAS}

INTRODUCTION: The West Virginia Office of $0 i 1$ and Gas has the authority to regulate all matters relating to oil and gas resources in the state. The West Virginia 0il and Gas laws contain 3 basic control measures: a permit to drill, a permit for underground storage, and a permit to plug or abandon a well.

The West Virginia $0 i 1$ and Gas Conservation Commission sets state policy with respect to conservation of oil and gas, and promotes the exploration and development of these resources.

\section{A. NAMES OF PERMITS:}

1. Permit to Drill

2. Permit for Underground Storage

3. Permit to Plug or Abandon a Well

B. AUTHORIZING STATUTE: 0 il and Gas Laws, Chapter 22, Article 4, Code of West Virginia

C. TITLE OF REGULATION: West Virginia Administrative Regulations, Department of Mines, Chapter 22-4

\section{SUMMARY OF PERMIT PROCESS:}

1. Applicability: To drill an oil or gas well; to plug or abandon an existing well; to construct underground storage; to drill a liquid injection or waste disposal well; or to redri11, deepen, fracture, stimulate, pressure, convert, combine, or cause any physical change that would allow the migration of fluid from one formation to another.

2. General Requirements: All persons owning, operating, or proposing to own or operate any oil or gas well in west Virginia must register with the Deputy Director of the Department of Mines.

3. Submission Requirements: An application for a permit to conduct these activities must be filed on appropriate forms and accompanied by a plat prepared by a licensed surveyor or engineer; information describing characteristics of the proposed we11, including its depth and proposed casing program; a surface reclamation plan; a performance bond of $\$ 2500$ per well; proof of a recorded lease and mineral ownership; information describing the proposed geological target formation; information describing proposed well construction; and a map showing the location of the well. 
4. Procedure for obtaining a Permit: once completed application materials are received, a hearing will be held within 10 to 30 days. Notice of the hearing must be provided in a local newspaper 10 days in advance of the hearing date. A final decision will be made by the Department within 15 days of the close of the hearing record.

5. Operation Requirements: Within 90 days of completing well drilling, the well operator must file an accurate log with the Deputy Director of the Department of Mines. An annual report of oil and gas production must also be filed with the Deputy Director. Operators of liquid injection and waste disposal wells must comply with regulations concerning casing and tubing, packer arrangements, and disposal of wastewater. Injection pressures and volumes must be monitored daily, recorded, and submitted to the Department. Al1 operators must comply with spacing and pooling requirements.

6. Fees: There is no permit fee. There is a $\$ 100$ reclamation fee for each well to help finance the plugging of orphan wells.

7. Appeals: Any party aggrieved by the issuance of a permit or refusal to grant a permit is entitled to a judicial review through the circuit court.

E. ADMINISTERING AGENCY: Office of $0 i 1$ and Gas

Department of Mines

1613 Washington Street, East

Charleston, WV 25311

(304) 348-2055 


\section{$3.1 .2 \quad \mathrm{COAL}$}

INTRODUCTION: The West Virginia Surface Coal Mining and Reclamation Act of 1980 was enacted in response to the Federal Surface Mining Control and Reclamation Act of 1977 (P.L. 95-87) to provide primary jurisdiction for the state over the surface mining of coal. The Act establishes general and specific guidelines for the surface mining of coal and for the reclamation of land impacted by surface and underground mining of coal.

The Reclamation Division of the Department of Natural Resources (DNR) has the responsibility for regulating these activities in the state. The Department of Mines has the responsibility for enforcing the mine safety laws in order to protect the health and safety of mine personnel and to protect and preserve mining property. Prior to engaging in surface coal mining and reclamation activities, all persons must obtain a surface mining permit from the Reclamation Division of the DNR. The permit application and related documents needed for granting a permit constitute a proposed mining and reclamation plan.

In addition to these major regulatory requirements, depending on the location, nature, and magnitude of the proposed activities, prospective mine operators may also be required to obtain the following permits, licenses, and approvals:

- a certificate of competentcy or permit of apprenticeship to operate a mine,

- certificates of qualification for mine forman and fire bosses,

- permits for the possession, use, and storage of explosives,

- certificate of approval to open a mine or reopen an abandoned mine,

- certificate of approval to prospect,

- a special permit for removal of coal incidental to the development of land,

- a coal preparation plant operating permit (air quality),

- other air quality permits (see Chapter 5.1 of this guide),

- certificate of approval to construct a dam (see Chapter 4.4 of this guide),

- water quality permits (See Chapter 5.2 of this guide), 
- solid and hazardous waste management permits (See Chapters 5.4 and 5.5 of this guide),

- clearance from the Department of Culture and History (See Chapter 6.2 of this guide),

- wetlands permits (See chapter 6.3 of this guide), and

- compliance with local zoning ordinances (See Chapter 7.1 of this guide).

Prospective mine operators should contact the DNR for clarification of regulatory requirements and procedures.

A. NAME OF PERMIT: Surface Mining Permit

B. AUTHORIZING STATUTES:

1. Chapter 20: Natural Resources, Article 6: West Virginia Surface Coal Mining and Reclamation Act (Section 20-6-1 et seg., Code of West Virginia)

2. Chapter 20: Natural Resources, Article 6C: Abandoned Mine Lands and Reclamation Act (Section 20-6C-1 et seq., Code of West Virginia)

3. Chapter 22: Mines and Minerals, Article 2: Coal Mines (Section 22-2-63 et seq., Code of West Virginia)

C. TITLE OF REgULATION: West Virginia surface Mining Reclamation Regulations, Chapter 20-6, Series VII, 1980 (proposed)

\section{SUMMARY OF PERMIT PROCESS:}

1. Applicability: All surface coal mining and reclamation activities.

2. General Requirements: Prior to engaging in surface and mining and reclamation activities, all persons must obtain a permit from the DNR Reclamation Division.

3. Submission Requirements: Applicants must submit an application on a form provided by the DNR which must include:

- the names and addresses of the permit applicant, the owner of record of the property, surface, and mineral to be mined, and the operator if different from the applicant; 
- a statement of any current surface mining permits held by the applicant in the state and each pending application;

- a copy of the required newspaper notice;

- a description of the type and method of the surface mining operation that exists or is proposed, the engineering techniques used or proposed, and the equipment used or proposed to be used;

- the name of the watershed and location of the surface stream or tributary into which surface and pit drainage will be discharged;

- a determination of the probable hydrologic consequences of the mining and reclamation operations, both on and off the mine site;

- all required maps according to regulatory specifications;

- a statement of the result of test borings or core samples from the permit area;

- for those lands in the permit application which a reconnaisance inspection suggests may be prime farm lands, a soil survey made according to the standards established by the Secretary of Agriculture in order to confirm the exact location of such prime farm 1 ands;

- the required reclamation plan according to regulatory specifications;

- information pertaining to coal seams, test borings, core samplings, or soil samples;

- when requested by the DNR, the climatological factors that are peculiar to the locality of the land to be affected;

- a blasting plan; and

- any additional information which may be reasonably necessary to effectuate the purposes of the Act. 
4. Procedure for Obtaining a Permit: Within 5 days of receiving an application, the DNR will notify the applicant in writing as to whether the application is complete.

The applicant must publish notice of the proposed mining activities at least once a week for 4 consecutive weeks in a local newspaper within the county of operation. The DNR will notify all appropriate Federal and State agencies, as well as local governmental bodies, planning agencies, sewage and water treatment authorities, and/or water companies in the locality of the proposed operation.

All notified Federal, State, and local agencies, as well as any interested or affected party may submit written comments or request an informal conference to be held on the application within 30 days of the last newspaper publication.

If so requested, a conference will be held by the DNR within 3 weeks after the close of the public comment period. The DNR must publish notice of such conference in a local newspaper within the county of the proposed operation at least 2 weeks prior to the scheduled conference date.

If no conference is held, the DNR will make a final determination on the application and notify the applicant in writing of its decision within 60 days of the filing date. If a conference is held, the final determination and notification will be made within 30 days of the close of the conference record.

After the permit application is approved but before the permit is issued, the operator must furnish a bond on a form provided by the DNR for $\$ 1,000$ per acre or fraction of an acre, conditioned upon the performance of all permit conditions and regulatory requirements.

5. Operation Requirements: Operators must commence activities covered by the permit within 3 years of the date of permit issuance. The proposed 1980 regulations call for complete inspection of all active surface mining operations every 30 days. Operators will then have 15 days to abate violations. Up to 75 days of extension time may be granted by the DNR at the discretion of the Director for good cause shown. Operators must establish and maintain all required records, submit all required monthly reports to the DNR, and install, use, and maintain all required monitoring equipment. All mining and reclamation activities must comply with all conditions established in the permit and with all applicable provisions of the Act and regulations.

6. Fees: Filing fee: $\$ 500$

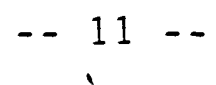


7. Appeals: Within 30 days after the applicant is notified of the decision of the DNR, the applicant or any party with an interest which may be adversely affected may request a hearing before the Reclamation Board of Review.

8. Special Notes: Chapter 22 of the Code of West Virginia establishes the mine safety laws for underground mines which are administered and enforced by the Department of Mines. Prior to initiating activities covered in this chapter, all persons must obtain approval from the Department of Mines. (See Section 22-1-1 et seq., Code of West Virginia)

E. ADMINISTERING AGENCIES: Reclamation Division

Department of Natural Resources

Building 3, Room 322

State Capitol

Charleston, WV 25305

(304) 348-3267

Mine Safety:

West Virginia Department of Mines

E-153 State Capitol

1800 Kanawha Boulevard, East

Charleston, WV 25305

(304) $348-2051$ 
CHAPTER 3.2

MINERALS MINING

INTRODUCTION: All provisions of the mining laws of the state intended for the protection of the health and safety of coal mine personnel and for the protection of any coal mining property also extend to the open-pit and underground mining of sand, gravel, sandstone, limestone, clay, shale, iron ore, and maganese ore. The Director of the Department of Mines is given the authority to adopt rules and regulations to enforce these provisions which cannot be more restrictive than the coal regulations. (See Sections 22-2B-1 et seq., 33-3-1 et seq., and 29A-1-1 et seq., Code of West Virginia) 
SECTION 4.0

LAND USE REGULATION

$13 a$ 


\section{CHAPTER 4.1 \\ MAJOR FACILITY SITING}

INTRODUCTION: The west Virginia Public service Commission has the authority to regulate the construction of any plant, equipment, property, improvement, or facility which would provide an extension of an existing power system.

A. NAME OF APPROVAL: Certificate of Public Convenience and Necessity

B. AUTHORIZING STATUTE: Public Service Commission, Chapter 24, Article 2, West Virginia Code

C. TITLE OF REGULATION: Rules and Regulations for the Government of Electric Utilities, Section 9: Transmission Line Construction

D. SUMMARY OF CERTIFICATION PROCESS:

1. Applicability: The construction of a high voltage transmission line of 200,000 volts or higher.

2. General Requirements: A certificate of public convenience and necessity is required prior to the construction of a new transmission line.

3. Submission Requirements: Appropriate application forms will be provided by the Commissioner of the Public Service Commission. Application materials must include a plat of the proposed line location; a description of the type of line to be constructed; a description of the width of the proposed right-of-way; a description of the proposed maintenance of the right-of-way; a statement describing the impact on wildlife in the right-of-way; a description of alternate routes investigated; and a statement justifying the need for the facility.

4. Procedure for obtaining a certificate: The applicant must publish a notice of intent in a local or county newspaper in which the line will be located. Interested parties may submit written comments to the Commission and/or request a hearing to be held on the application within 30 days of the application filing date. If so requested, a public hearing will be held. The Commission will make a final determination on the application within 60 days of the application filing date if no hearing is held or within 90 days of the application filing date if a hearing is held.

5. Operation Requirements: Operation requirements are included as conditions in the issued certificate and are based on case record. 
6. Fees: None

7. Appeals: Persons aggrieved by a final decision of the Commission may appeal to the appropriate circuit court.

E. ADMINISTERING AGENCY: Public Service Commission State Capitol

Charleston, WV 25304

(304) 348-2182 


\section{CHAPTER 4.2 \\ LAND USE}

INTRODUCTION: The State of West virginia has no state land use legislation. Local governments are permitted to adopt and enforce land use legislation locally. 


\section{FLOOD PLAIN MANAGEMENT}

INTRODUCTION: West Virginia does not have a State program to regulate flood plain development. Counties and municipalities with flood-prone areas regulate such development through participation in the National Flood Insurance Program. A total of 264 counties and municipalities in the State participate in the program, with 201 in the emergency phase and 63 in the regular phase. Most of these local government units have enacted ordinances limiting development in designated flood-prone areas. The State office of Emergency Services assists counties and municipalities in complying with Federal flood plain regulations.

ADMINISTERING AGENCY:

Governor's Office of Economic and Community Development

1900 Washington Street, East

Charleston, WV 25305

(304) 348-0400 
INTRODUCTION: The Dam Control Act of 1973 was enacted to provide for regulation and supervision of dams in the state of West Virginia to the extent necessary to protect public health, safety, and welfare. The basic regulatory control is a certificate of approval for the modification or construction of any dam or reservoir in the State, issued by the Department of Natural Resources.

A. NAME OF APPROVAL: Certificate of Approval for Construction or Modification of a Dam or Reservoir

B. AUTHORIZING STATUTE: Dam Control Act of 1973, Article 5D, Section 20-5D-1 through 20-5D-14, West Virginia Code

C. TITLE OF REgULATION: There are no regulations. However, the Department of Natural Resources has established a procedure for obtaining a certificate of approval.

\section{SUMMARY OF CERTIFICATION PROCESS:}

1. Applicability: The construction, enlargement, alteration, repair, or removal of any part of any dam or reservoir.

2. General Requirements: Prior to starting a regulated activity, a certificate of approval must be obtained from the Department of Natural Resources, Division of Reclamation, Coal Refuse and Dam Control Section.

3. Submission Requirements: A completed application form must be submitted to the Department of Natural Resources. The application must include all plans, specifications, and supporting calculations. All design specifications must be prepared by a registered professional engineer.

4. Procedure for Obtaining a Certificate: Applications are reviewed by the Coal Refuse and Dam Control Section staff to determine completeness. No application will be considered complete until all corrections or additions have been made. The applications are then approved for public notice or are rejected. After approval, the applicant must publish a Class I legal advertisement. Interested parties may submit written comments concerning the application within 15 days of the notice publication date. If no protests are received during this 15-day comment period, the certificate of approval will be issued. 
5. Operation Requirements: Monthly progress reports, including quality assurance data, must be submitted to the Division. Annual reports prepared by a qualified engineer must be submitted to the Division. These reports must include summaries of instrumentation readings; conditions of slopes, appurtenances, and changes in water level; conclusions; and plans to carry out any necessary maintenance.

\section{Fees: Filing fee: $\$ 25$}

7. Appeals: Any person adversely affected by a decision has the right of judicial review by appeal to the appropriate circuit court.

E. ADMINISTERING AGENCY: Coal Refuse and Dam Control Section

Division of Reclamation

Department of Natural Resources

Building 3, Room 322

1800 Washington Street, East

Charleston, WV 25305

(304) 348-3267 
SECTION 5.0

ENVIRONMENTAL QUALITY MANAGEMENT 


\section{AIR QUALITY}

INTRODUCTION: The Air Pollution Control Law of west virginia was enacted to implement the Federal Clean Air Act of 1970 and Clean Air Amendments adopted since 1970. The Air Pollution Control Commission, the agency responsible for air quality planning, implementation, monitoring, and enforcement, has adopted regulations to implement the West virginia act. The regulations require permits for construction, modification, or relocation of stationary sources of air pollutants; provide procedures for registration and evaluation of those sources; and set emission standards.

A. NAME OF PERMIT: Construction Permit

B. AUTHORIZING STATUTE: Air Pollution Control Law of west Virigina, Chapter 16, Article 20, Sections 16-20-1 through 16-20-13, 1961, as amended, Code of West Virginia

C. TITLE OF REGULATION:

1. Construction Permits: West Virginia Administrative Regulations, Air Pollution Control Commission, Chapter 16-20, Series XIII (1974)

2. Air Emission Standards: West Virginia Administrative Regulations, Air Pollution Control Commission, Chapter 16-20, Series I through XII (1974)

D. SUMMARY OF PERMIT PROCESS :

1. Applicability: The construction or modification of a direct or indirect affected source of air pollution emissions, or the relocation of a direct affected source.

2. General Requirements: All direct affected sources must be registered as sources with the Air pollution control Commission. A construction permit is necessary for new sources of air pollution.

3. Submission Requirements: Applications to construct, modify, or relocate sources of air pollution must be filed with the Director of the Air pollution Control Commission. Permit application materials must include the name of the applicant, information describing type of facility, location drawings, a description of proposed control devices for each source, start-up dates for each source, schematic diagrams of each source and control device, a detailed identification of 
source characteristics for each source and of each pollution control device, a description of the detailed characteristics of particulate matter, and a description of potential sources of fugitive particulate matter generation.

4. Procedure for obtaining a Permit: Permit applications for construction of a direct source must be filed with the Director of the Air Pollution Control Commission at least 90 days prior to the anticipated construction or modification starting date, or at least 45 days prior to the anticipated relocation date. Applicants must place a legal advertisement in the affected area's local newspaper at the time of filing. The Commission makes a technical review of the completed application. Within 60 days of receipt of the application, the Director of the Commission places the application on a list of permit applications available for public review, receives written comments, and may decide to hold public meetings during the comment period. The Director has 90 days (45 days for relocation) to approve the permit (conditionally or unconditionally), to deny the permit and issue an order to prevent construction, or to take no action, whereby a permit is automatically considered approved.

For construction or modification of an indirect source, application materials must be submitted at least 90 days prior to the anticipated construction start-up date. A technical review of completed applications is made by Commission staff. Within 30 days of receiving complete applications, the Director places a legal advertisement in the affected area's local newspaper and makes application information available for public inspection in the area. A 30-day comment period is allowed and public meetings are held, if deemed necessary by the Director. The Director makes a final decision on the application within 90 days of the filing date.

5. Operation Requirements: Construction must begin within 6 months of the date of permit issuance. Operators must comply with all plans, specifications, and conditions established in the permit. The Commission has established administrative regulations stating operating standards to which operators must comply:

Series I:

Prevent and control air pollution from coal refuse disposal areas. (Enacted November 15 , 1963 )

Series II: Prevent and control particulate air pollution from combustion of fuel in indirect heat exchange. (Enacted July 23, 1974) 
Series III: Prevent and control air pollution from the operation of hot mix asphalt plants. (Enacted February 23, 1979)

Series IV: Prevent and control the discharge of air pollutants into the open air which cause or contribute to an objectionable odor or odors. (Enacted August 17, 1967)

Series V: Prevent and control air pollution from the operation of coal preparation plants and coal handling operations. (Enacted September 1, 1968)

Series VI: Prevent and control air pollution from combustion or refuse. (Enacted February 23, 1979)

Series VII: Prevent and control particulate air pollution from manufacturing plant operations. (Enacted February 23, 1979)

Series VIII: Prevent and control air pollution from the emission of sulfur oxides. (Enacted september 7,1978 )

Series IX: Prevent air pollution emergency episodes. (Enacted January 19, 1972)

Series $x$ : Ambient air quality standards for sulfur oxides and particulate matter. (Enacted January 8, 1979)

Series XI: Ambient air quality standards for carbon monoxide, non-methane hydrocarbons, and photochemical oxidants. (Enacted April 22, 1980)

Series XII: Ambient air quality standards for nitrogen dioxide. (Enacted January 19, 1972)

Series XVII: Prevent and control particulate air pollution from materials handling, preparation, and storage and sources of fugitive particulate matter. (Enacted February 23, 1979)

Series XXI: Prevent and control air pollution from the emission of volatile organic compounds from the storage of petroleum liquids in fixed roof tanks. (Enacted May 9, 1979) 
Series XXIII: Prevent and control air pollution from the emission of volatile organic compounds from bulk gasoline terminals. (Enacted May 8, 1979)

Series XXIV: Prevent and control air pollution from the emission of volatile organic compounds from petroleum refinery sources. (Enacted May 8 , 1979)

6. Fees: None

7. Appeals: Any party adversely affected by any Commission decision may appeal to the Commissioner within 30 days of receipt of that decision.

E. ADMINISTERING AGENCY: West Virginia Air Pollution Control Commission 1558 Washington Street, East Charleston, WV 25311

(304) $348-2275$ 


\section{WATER QUALITY STANDARDS AND REGULATIONS}

INTRODUCTION: West virginia is currently in the process of adopting regulations that would allow the state to receive primacy in the administration of the National Pollutant Discharge Elimination system (NPDES). The proposed regulations are designed to prevent, control, eliminate, and reduce pollution of the State's waters. The proposed regulations are divided into 3 chapters: water quality standards, requirements governing the State NPDES program, and special regulations. The basic means of control include a discharge permit, water quality standards, and effluent limitations. Until the state recieves primacy, an NPDES permit from the U.S. Environmental Protection Agency (EPA) is also necessary and the State will continue to operate under the 1977 Administrative Regulations for Water Quality Criteria on Inter-and Intrastate Streams, administered by the Department of Natural Resources.

\section{A. NAMES OF PERMITS:}

1. NPDES Permit

2. Water Pollution Control Permit

B. AUTHORIZING STATUTE: West Virginia water pollution control Act, Chapter 20, Article 5 and Article 5A, West Virginia Code

C. TITLE OF REgULATION: West Virginia Administrative Regulations, State Water Resources Board, Chapters 20-5 and $20-5 A$

\section{SUMMARY OF PERMIT PROCESS:}

1. Applicability: The discharge or the increased discharge of pollutants from a point source into state waters; construction, operation, or modification of a disposal system for direct or indirect discharge of treated or untreated waste into state waters.

2. General Requirements: A State NPDES permit from the Division of Water Resources is necessary for the above activities, along with the NPDES permit from the U.S. EPA until such time as state primacy is obtained. U.S. EPA-issued NPDES permits will then be accepted as State-issued permits. 
3. Submission Requirements: Anyone proposing to discharge pollutants must submit an application to the Division of Water Resources. Application materials must include up to 4 Standard Industrial classification (SIC) codes which best reflect the principal products or services provided by the facility, a topographic map, and a description of the nature of the business. Existing dischargers must include additional information describing effluent characteristics.

4. Procedure for Obtaining a Permit: On receiving an application, the Division chief will review the application for completeness and notify the applicant. Once deemed complete, the chief has 90 days to make a permit decision.

The chief will decide whether or not to prepare a draft permit. If a draft permit is prepared, a public hearing may be held after a 30-day notice of the hearing. Draft permits will contain all compliance schedules and monitoring requirements; effluent limitations, standards, prohibitions, and conditions; and all variances that are to be included. A fact sheet may also be prepared if the proposed project is the subject of widespread public interest. Permits are valid for up to 5 years.

5. Operation Requirements: A number of standards, limitations, and other requirements may be incorporated into the permit to ensure compliance with general water use categories and water quality criteria. Any discharge may be subject to inspection. Permittees must retain records of all monitoring activities.

6. Fees: Filing fee: $\$ 50$

7. Appeals: Any person adversely affected by an order from the chief may appeal to the Water Resources Board.

E. ADMINISTERING AGENCY: Division of Water Resources

Department of Natural Resources

1201 Greenbrier Street

Charleston, WV 25311

(304) 348-2107 


\section{CHAPTER 5.3 \\ PUBLIC WATER SUPPLY}

INTRODUCTION: The West Virginia Public water Supply Regulations, administered by the Department of Health, form the basis for a comprehensive program to help protect the quality of the drinking water in the state. The basic regulatory controls include a permit to construct and a permit to operate a public water supply system.

\section{A. NAMES OF PERMITS:}

1. Permit to Construct

2. Permit to operate

B. AUTHORIZING STATUTE: Chapter 16, Article 1, Public Health Laws, Code of West Virginia, 1931, as amended

C. TITLE OF REgULATION: West Virginia State Board of Health, Chapter 1, Article 5: Public Water Supply Regulations; Article 5A: Public Water Supply Operator Regulations

\section{SUMMARY OF PERMIT PROCESS:}

1. Applicability: The construction, alteration, or renovation of a public water supply system, or the awarding of a contract for the construction, alteration, or renovation of a public water supply system; the operation of a public water supply system.

2. General Requirements: A permit is required to construct or operate a water supply system. Certification of system operators is also required.

3. Submission Requirements: An application for a water supply system construction permit must be submitted to the Director of the Department of Health on designated forms and must be accompanied by an engineering report, maps, and detailed plans and specifications prepared by a registered professional engineer. Application materials must be submitted at least 45 days prior to the anticipated construction start-up date.

An application for a permit to operate a water supply system must be made to the Director at least 30 days prior to the scheduled operation of the system. 
4. Procedure for obtaining a Permit: once completed application materials are submitted, the Director will either approve or disapprove the permit application. Plans and specifications for the project must be in compliance with the West Virginia State Department of Health's "Design Standards for Public Water Supply Systems" (Bulletin No. EW-99).

5. Operation Requirements: Each public water supply system utilizing surface water will be inspected by the Director at least once a year. Other systems will be inspected as scheduled by the Director. Owners or operators of such systems must retain records of turbidity and microbiological, radiological, and chemical analyses. Operation standards and criteria are detailed in sections 6 through 10 of the Regulations. Any required test results must be submitted to the Director within 45 days. Any compliance failures must be reported within 48 hours. A monthly report on all testing and monitoring must be submitted to the Director. All persons operating a public water supply system must be certified by the Office of Environmental Health Services in accordance with Chapter 1, Article 5A, Public Water Supply Operator Regulations.

6. Fees: None

7. Appeals: Persons aggrieved by a final decision of the Department of Health may appeal to the appropriate circuit court.

E. ADMINISTERING AGENCY: Office of Environmental Health

Services

Department of Health

208 State Office Building 3

1800 Washington Street, East

Charleston, WV 25305

(304) 348-2981 


\section{SOLID WASTE MANAGEMENT}

INTRODUCTION: The Public Health Laws of West Virginia, administered by the Department of Health, authorize the regulation of the design, construction, installation, and methods of operation of solid waste disposal systems. At present, proposed regu1 ations require a permit to construct and a permit to operate.

\section{A. NAMES OF PERMITS:}

\section{Permit to Construct \\ 2. Permit to Operate}

B. AUTHORIZING STATUTE: Chapter 16, Article 1, Public Health Laws, West Virigina Code, 1931, as amended

C. TITLE OF REgULATION: West Virginia State Board of Health, Chapter 1, Article 12, Solid Waste Disposal Regulations, 1974 (Proposed)

D. SUMMARY OF PERMIT PROCESS:

1. Applicability: The construction or operation of a solid waste disposal facility.

2. General Requirements: A permit is required to construct or operate a solid waste facility.

3. Submission Requirements: An application for a permit must be submitted to the Department of Health on prescribed forms and must contain all pertinent information relative to location, site, and acreage; a cost estimate; a description of terrain, amount of waste to be handled and method of financing; a facility engineering design; construction specifications; and other information as required by the Department.

4. Procedure for obtaining a Permit: Once application materials are submitted to the Department, the site is evaluated. If the site is found to be suitable, the applicant submits an operating plan. Once approved, a permit is issued for the type of waste to be handled. If construction of the facility does not begin within 6 months, the permit automatically expires. Permits become invalid at a change of ownership of a facility. 
5. Operation Requirements: All solid waste disposal facilities must be constructed, modified, and operated in accordance with the applicable standards contained in the West Virginia Department of Health, Solid Waste Program Bulletin SWP-D1, "Design Standards for Solid Waste Disposal." Permits may be suspended for any deficiency constituting a health or pollution hazard; for an overloaded facility due to mechanical, geological, or weather conditions; or for failure to adhere to plans approved for the site. A landfill facility operation must be supervised continuously during operating hours by a trained person and a daily log must be maintained.

Solid waste is rated according to 3 classes: Class 1: wastes of a hazardous nature; class 2: decomposable organic materials; and Class 3 : nondecomposable material presenting only confinement and aesthetic problems. Each class requires specific disposal methods as detailed in Section 6 of the Regulations.

\section{Fees: None}

7. Appeals: Any person aggrieved by a notice of suspension, revocation, permit denial, or other order may, within 10 days after receiving the notice, petition the Director for a hearing.

8. Special Notes: Generally, permits apply to organized disposal, such as a community or commercially operated facilities.

E. ADMINISTERING AGENCY: Solid Waste Division

Office of Environmental Health

$$
\text { Services }
$$

Department of Health

541 State office Building 3

1800 Washington Street, East

Charleston, WV 25305

(304) $348-2987$ 


\section{CHAPTER 5.5}

\section{HAZARDOUS WASTE MANAGEMENT}

INTRODUCTION: The West Virginia Hazardous Waste Management Act was passed April 11, 1981 by the West Virginia Legislature. The Act establishes a program for the regulation and management of hazardous waste storage, transportation, treatment, and disposal and will enable the state to assume regulatory primacy as allowed by Subtitle $C$ of the Federal Resource Conservation and Recovery Act (RCRA). Under the Act, the Department of Natural Resources (DNR) is designated as the lead agency and is required to publish a study of hazardous waste management in the state which must include an inventory of existing and abandoned sites.

The Director of DNR is given rule-making authority and directed to coordinate such rule making with other agencies in the state such as the Air Pollution Control Commission, Department of Health, Department of Highways, Public Service Commission, Reclamation Commission, and $0 i l$ and Gas Commission. Major permitting authority is given to the Water Resources Division (WRD). Any person who constructs, modifies, operates, or closes a hazardous waste facility must have a permit from the WRD. Major facility operators will also be required to submit an environnmental analysis with their permit application.

The Act provides for a transition program for existing facilities which are in compliance with the interim status requirements of RCRA. Inspection authority is given to the agencies covered under the Act. They are also authorized to issue orders requiring compliance; suspension, revocation, or modification of permits; and cease and desist orders. Criminal and civil penalties and provisions for citizen suits are also included in the Act. Persons aggrieved by orders of the Chief of the WRD may appeal to the Water Resources Board.

Regulations are authorized to be promulgated within 6 months of the effective date of the Act.

ADMINISTERING AGENCY:

Water Resources Division

Department of Natural Resources

1201 Greenbrier Street

Charleston, WV 25311

(304) 348-5935 


\section{CHAPTER 5.6 \\ NOISE REGULATIONS}

INTRODUCTION: The West virginia state statutes contain no authorization for the regulation of noise levels or for the establishment of standards within the state. 
SECTION 6.0

SOCIAL/ECOLOGICAL PRESERVATION

$31 a$ 


\section{RARE AND ENDANGERED SPECIES}

INTRODUCTION: The Wildlife Resources Division of West Virginia's Department of Natural Resources is responsible for administering a scientific collecting permit program for wildlife within the State.

\section{A. NAME OF PERMIT: Scientific Collecting Permit}

B. AUTHORIZING STATUTE: Chapter 20, Natural Resources, Article 2, Wildlife Resources, Section 50, Code of West Virginia

C. TITLE OF REgULATION: No regulations have been adopted. Permitting procedures and regulatory requirements are included in the statute.

\section{SUMMARY OF PERMIT PROCESS:}

1. Applicability: Hunting, killing, taking, capturing, or maintaining in captivity any wildlife species, including reptiles, for scientific or propogation purposes.

2. General Requirements: Prior to starting a regulated activity, a11 persons must obtain a scientific collecting permit from the Wildlife Resources Division.

3. Submission Requirements: Appropriate application forms must be submitted to the Division and must describe the following information: applicant's profession and professional association, method and purpose of collection, disposal of specimens, date and location of collection activity, the scientific name of the species to be collected, and the number of species to be collected.

4. Procedure for Obtaining a Permit: After an application is submitted to the Wildlife Resources Division, a committee reviews the material and comments as to whether or not a permit should be issued. Comments are compiled and sent to the chief of the Division for final decision. If approved, the permit is issued. If a permit is denied, a letter is sent to the applicant explaining what changes or special provisions must be made to obtain a permit.

5. Fees: None

6. Appeals: Persons aggrieved by a final decision of the Department of Natural Resources may appeal to the appropriate circuit court. 
7. Special Notes: Permits for activities such as keeping pets, maintaining roadside menageries, or commercial fishing preserves must also be obtained from the Wildlife Resources Division.

E. ADMINISTERING AGENCY: Wildlife Resources Division Department of Natural Resources 1800 Washington Street, East Charleston, WV 25305 (305) $348-2707$ 
CHAPTER 6.2

ARCHAEOLOGICAL AND HISTORICAL

INTRODUCTION: There are no regulations or permit processes dealing specifically with archaeological or historic preservation at the State level in West Virginia. Generally, where appropriate, Federal preservation legislation is administered by the Historic Preservation Unit of West Virginia's Department of Culture and History. This agency reviews projects involving cultural resources and the State Historic Preservation officer is responsible for issuing opinions on these projects. Archaeological and historic clearance by the Department of Culture and History is currently required prior to the issuance of a surface mining permit by the Department of Natural Resources.

ADMINISTERING AGENCY: Historic Preservation Unit Department of Culture and History State Capitol

Charleston, WV 25305

(304) 348-0240 


\section{CHAPTER 6.3}

\section{WETLANDS}

INTRODUCTION: There are no regulations or permit processes dealing exclusively with protection of wetlands in the state. However, the State Department of Natural Resources works in conjunction with the U.S. Army Corps of Engineers to evaluate and act on proposals affecting wetlands, as part of the corps' Section 404 permit process. In those cases where wetlands would be affected by a proposed development, the state and the corps each hold public hearings on the proposal.

ADMINISTERING AGENCY: Division of Environmental Analysis

Department of Natural Resources

State Capitol

Charleston, WV 25305

(304) $348-2761$ 
SECTION 7.0

LOCAL REGULATORY POLICY

$35 a$ 


\section{LOCAL GOVERNMENT LAND USE AND \\ NATURAL RESOURCE CONTROL ENABLING LAWS}

INTRODUCTION: In the state of West Virginia, local jurisdictions are delegated basic planning, zoning, and subdivision powers and authority from the state under one major enabling article.

A. AUTHORIZING STATUTE: Chapter 8, Article 24, Intergovernmental Relations -- Urban and Rural Planning and Zoning, Sections 1 through 71

B. SUMMARY OF ENABLING LEGISLATION: Under this Article, the governing body of every municipality and the county court of every county may, by ordinance, create a planning commission to promote orderly development of its governmental units and their environs. The planning commission must develop a comprehensive plan for the physical development of territory within its jurisdiction. The governing body of the municipality or county also has full zoning powers and has the power to administer subdivision regulations.

C. ADMINISTERING AGENCIES: Individual cities and towns within the State of West Virginia

For more information contact: Community Development Division Governor's Office of Economic and Community Development 1900 Washington Street, East Charleston, WV 25305 (304) 348-0400 